\title{
ANALIZA NUMERYCZNA ZMIAN NAPRĘ̇̇EŃ W KONSTRUKCJI ŚCIANY WYWOLANYCH NIECIĄGŁYMI DEFORMACJAMI PODŁOŻA GÓRNICZEGO
}

\begin{abstract}
Efektem podziemnej eksploatacji kopalin na powierzchni terenu są osiadania powierzchni. W większości przypadków są to deformacje tzw. ciągłe, które ujawniają się w postaci łagodnej niecki obniżeń, jednak w określonych przypadkach mogą się pojawić deformacje nieciągłe. Ich sposób ujawniania się jest gwałtowny, a zabezpieczenie konstrukcji znajdującej się na powierzchni terenu jest trudne.

W referacie przedstawiono analizę numeryczną układu budowla-podłoże obciążonej ujawniającymi się nieciągłymi deformacjami podłoża. Analizę przeprowadzono z wykorzystaniem niekomercyjnego oprogramowania MAFEM3D, które zostało opracowane przez prof. Majewskiego. Program stosuje przyrostowo-iteracyjną procedurę MES z wykorzystaniem sprężysto-plastycznego modelu materiałowego z izotropowym wzmocnieniem i osłabieniem. Zastosowanie tego modelu materiałowego umożliwiło opracowanie modelu konstrukcji muru ceglanego oraz podłoża, który został obciążony nieciągłą deformacją terenu. Analizę przeprowadzono dla jednego geometrycznego modelu ściany z różnymi wykorzystanymi materiałami konstrukcyjnymi i elementami wzmacniającymi. Obciążenia zostały zaimplementowane jako próg terenowy, który obejmował różną długość fundamentu. W trakcie analizy wyników brane pod uwagę były zmiany naprężeń w konstrukcji i podłożu. Poziom wytężenia każdego elementu skończonego przedstawia strefy wyczerpania nośności, co może wskazywać na powstanie zarysowań w konstrukcji lub uplastycznień w podłożu.

Wyniki analiz numerycznych dają obiecujące rezultaty, które jednak należy ograniczyć do konkretnej konstrukcji ściany. Dalsze etapy analiz powinny zostać rozszerzone na pełną analizę trójwymiarową i przestrzenną współpracę elementów konstrukcyjnych (ściany, płyty stropowe). Należy również rozważyć różny rodzaj parametrów gruntowych oraz lokalizacji progu w stosunku do fundamentów. Przedstawiona analiza jest wstępna, a wyniki mają charakter jakościowy.
\end{abstract}

Słowa kluczowe: nieciągłe deformacje podłoża, układ budowla-podłoże, analiza MES, sprężysto-plastyczny model materiałowy

\footnotetext{
${ }^{1}$ Leszek Szojda, Politechnika Śląska, Katedra Inżynierii Budowlanej, ul. Akademicka 5, 44-100 Gliwice tel. 3223725 92; leszek.szojda@polsl.pl
} 


\section{Wprowadzenie}

Inżynierskie odejście do projektowania konstrukcji budowlanych sprowadza się do spełnienia warunku Stanów Granicznych, w których oddziaływania zewnętrzne nie wywołują skutku większego niż nośność elementów konstrukcyjnych. Zadaniem projektanta jest właściwe zebranie wszystkich obciążeń działających na obiekt i ułożenie ich w odpowiednie kombinacje zgodne z normami [1], co jest kluczem do poprawnego zaprojektowania konstrukcji. Całe oddziaływania konstrukcji należy bezpiecznie sprowadzić na podłoże projektując właściwe fundamenty. Można znaleźć jednak przypadki kiedy podłoże staje się aktywnym oddziaływaniem wywołującym obciążenia konstrukcji. Sytuacja taka występuje w rejonach aktywności górniczej, gdzie na skutek podziemnej eksploatacji złoża powstają pustki poeksploatacyjne, które zostają wypełnione nadległymi skałami, a na powierzchni pojawia się strefa obniżeń. Polskie warunki geologiczne oraz znaczna głębokość eksploatacji złóż wywołują łagodne strefy obniżeń $[2,3,4]$. Określane są one jako ciągłe deformacje podłoża. Oddziaływań tych jednak nie można pominąć w procesie projektowania obiektów w takiej strefie, gdyż w skrajnych przypadkach mogą doprowadzić do uszkodzeń wyłączających obiekt z eksploatacji. Znacznie bardziej niebezpieczne i obciążające konstrukcje są nieciągłe deformacje podłoża. Zalicza się do nich efekty uaktywnienia i wypełnienia podziemnych pustek położonych blisko powierzchni terenu (jaskiń lub starych wyrobisk górniczych) lub progów terenowych czy uskoków. Należy jednak zauważyć, że eksploatacja górnicza prowadzona jest w głębiej położonych warstwach skalnych skorupy ziemskiej, a obiekty budowlane posadowione są w warstwie skał rozdrobnionych - gruntów spoistych i niespoistych. Warstwa ta spełnia rolę swoistego amortyzatora i częściowo łagodzi efekty zjawisk krawędziowych deformacji nieciągłych. Analiza zachowania konstrukcji poddanej działaniu takiej deformacji podłoża powinna być prowadzona zarówno w odniesieniu do konstrukcji jak i do podłoża, a więc należy rozpatrywać tzw. układ budowla-podłoże.

Niniejszy referat ma za zadanie przybliżenie i przedstawienie zachowania się konstrukcji oraz podłoża w procesie ujawniania się krawędzi deformacji nieciągłych. Analiza numeryczna została przeprowadzona dla jednego elementu konstrukcyjnego budynku mieszkalnego jakim jest ściana. Obciążenia w postaci progu terenowego zostały przyłożone w różnym miejscu na długości fundamentu, a analizie poddano również zmianę naprężeń w podłożu. Można było tego dokonać dzięki zastosowaniu zaawansowanego modelu numerycznego materiału w doniesieniu zarówno do konstrukcji, jak i do podłoża.

\section{Przyjęty model materiałowy}

Model materiałowy zastosowany w obliczeniach numerycznych ma bardzo istotne znaczenie dla wyników obliczeń. W przedstawionym zagadnieniu ko- 
nieczne jest przyjęcie układu budowla-podłoże i odpowiednie wprowadzenie obciążeń, które są w tym przypadku przemieszczeniami podłoża. Dla rozważenia tego zagadnienia posłużono się niekomercyjnym pakietem programów o nazwie MAFEM3D autorstwa prof. S. Majewskiego z częścią do prezentacji wyników autorstwa dr G. Wandzika. Dokładny opis modelu przedstawiono w pracach [5] i [6]

Obliczenia numeryczne zostały wykonane $\mathrm{z}$ wykorzystaniem sprężystoplastycznego modelu materiałowego ze stowarzyszonym prawem płynięcia i dwuparametrowym, izotropowym prawem wzmocnienia względnie osłabienia. Model ten zalicza się do grupy nasadkowych modeli sprężysto-plastycznych (cap model) bez punktów osobliwych z rozmytym obrazem zarysowania (smeared crack).

W obszarze sprężystym założono nieliniową sprężystość charakteryzowaną stycznymi: modułem sprężystości $E_{t}$ i współczynnikiem Poissona $v_{t}$, zależnymi od poziomu wytężenia. Wspomniany stopień wytężenia (oznaczany $e_{\text {lev }}$ effort level) rozumiany jest jako iloraz odległości mierzonej od osi naprężeń średnich do punktu reprezentującego aktualny stan naprężenia, w stosunku do odległości mierzonej od tej samej osi do punktu leżącego na powierzchni granicznej, odpowiadającego aktualnej wartości naprężenia średniego.

Sprężyste zachowanie materiału w przestrzeni naprężeń oktaedrycznych jest ograniczone powierzchnią plastyczności (yield surface) oraz ograniczającą (boundary surface). W przedstawionym zagadnieniu przyjęto dla zastosowanych materiałów założenie upraszczające o nie domknięciu powierzchni w strefie dużych ściskań. Założenie to przyjęto ze względu na zakres hydrostatycznych naprężeń ściskających, które nie pojawiają się w trakcie analiz typowych konstrukcji budynków. Dla betonu i muru ceglanego przyjęto dodatkowe założenie o pokrywaniu się obydwu powierzchni, natomiast dla elementów podłoża gruntowego powierzchnia plastyczności znajduje się wewnątrz powierzchni granicznej. W trakcie występowania przyrostu obciążenia, gdy naprężenia osiągają powierzchnię plastyczności, powierzchnia ta powiększa się i w ostatecznym przypadku może osiągnąć powierzchnię stanu granicznego. $Z$ tego też powodu, pomimo że charakter powierzchni dla obu rodzajów materiałów jest podobny, mają one różne charakterystyki w obszarze poza sprężystym.

Określenie stanu naprężenia w elemencie w przestrzeni naprężeń oktaedrycznych jest prezentowane w walcowym układzie współrzędnych [7], którego wartości są wyznaczane przez $\sigma_{o c t}$ (normalne naprężenie oktaedryczne) (1), $\tau_{\text {oct }}$ (styczne naprężenie oktaedryczne) (2) oraz $\Theta$ (kąt Lodego) (3). Do wyznaczenia tych zmiennych wykorzystano drugi $J_{2}(4)$ oraz trzeci niezmiennik dewiatora stanu naprężenia $J_{3}(5)$.

$$
\sigma_{o c t}=\sigma_{m}=\frac{\sigma_{x}+\sigma_{y}+\sigma_{z}}{3}=\frac{\sigma_{1}+\sigma_{2}+\sigma_{3}}{3}
$$




$$
\begin{aligned}
& \tau_{o c t}=\sqrt{\frac{2}{3} J_{2}}=\sqrt{\frac{1}{3}\left[\left(\sigma_{1}-\sigma_{m}\right)^{2}+\left(\sigma_{2}-\sigma_{m}\right)^{2}+\left(\sigma_{3}-\sigma_{m}\right)^{2}\right]} \\
& \cos 3 \Theta=\frac{3 \sqrt{3}}{2} \frac{J_{3}}{J_{2}^{3 / 2}} \\
& J_{2}=\frac{1}{2}\left[\left(\sigma_{x}-\sigma_{m}\right)^{2}+\left(\sigma_{y}-\sigma_{m}\right)^{2}+\left(\sigma_{z}-\sigma_{m}\right)^{2}\right]+\tau_{x y}^{2}+\tau_{y z}^{2}+\tau_{z x}^{2} \\
& J_{3}=\left|\begin{array}{ccc}
\sigma_{x}-\sigma_{m} & \tau_{x y} & \tau_{x z} \\
\tau_{y x} & \sigma_{y}-\sigma_{m} & \tau_{y z} \\
\tau_{z x} & \tau_{z y} & \sigma_{z}-\sigma_{m}
\end{array}\right|
\end{aligned}
$$

Powierzchnia plastyczności oraz powierzchnia graniczna zostały zdefiniowane jako stożki, których osie pokrywają się z osią normalnych naprężeń oktaedrycznych $\sigma_{o c t}$. Wierzchołek tego stożka znajduje się po stronie naprężeń dodatnich (rozciągających) w tym układzie współrzędnych. W przekroju dewiatorowym ślad stożka powierzchni ma kształt wygładzonej linii elips przechodzących przez sześciokąt modelu Coulomba-Mohra. Zastosowanie elips zostało zaczerpnięte $\mathrm{z}$ modelu [8]. W strefie rozciągań powierzchnia ograniczona jest stycznie połączoną nasadką. Tworzące stożka wyznaczone są zatem przez linie proste w strefie naprężeń ściskających $\sigma_{o c t}$, natomiast w strefie początku układu współrzędnych oraz naprężeń rozciągających przez parabole. Przejście pomiędzy paraboliczną i prostoliniową częścią południków znajduje się $\mathrm{w}$ tzw. punkcie styczności $\left(S_{t}\right)$. Wszystkie tworzące stożka przecinają się w jednym punkcie na osi $\sigma_{o c t}$, który określany jest jako wytrzymałość w stanie równomiernego trójosiowego rozciągania $\left(f_{t t t}\right)$. Brak danych doświadczalnych nie pozwala określić przecięcia w strefie naprężeń ściskających $\left(f_{c c c}\right.$ - wytrzymałość w stanie równomiernego trójosiowego ściskania) i powierzchnia pozostaje w tej strefie otwarta. Ślad powierzchni w układzie południków głównych oraz w przekroju dewiatorowym przedstawiono na rys. 1 .

Ze względu na charakterystyczny kształt powierzchni w przekroju dewiatorowym można wyznaczyć dwie grupy południków głównych - południk rozciągania i południk ściskania. W walcowym układzie współrzędnych położenie tych południków powtarza się co $120^{\circ}$, a południki ściskania są odchylone od południków rozciągania o kąt $60^{\circ}$. Na południkach tych położone są punkty charakterystyczne, i tak: południk ściskania zawiera punkt określający wytrzymałość materiału w stanie jednoosiowego ściskania $\left(f_{c}\right)$, natomiast na południku rozciągania znajduje się wytrzymałość w stanie jednoosiowego rozciągania $\left(f_{t}\right)$ oraz wytrzymałość w stanie równomiernego dwuosiowego ściskania $\left(f_{c c}\right)$. 
Każdy z materiałów opisany został za pomocą południków różniących się między sobą. Południki dla betonu i gruntu zostały przyjęte na podstawie [5], natomiast ujednolicone parametry dla muru składającego się z zaprawy i cegły przyjęto na podstawie badań przedstawionych w [9].

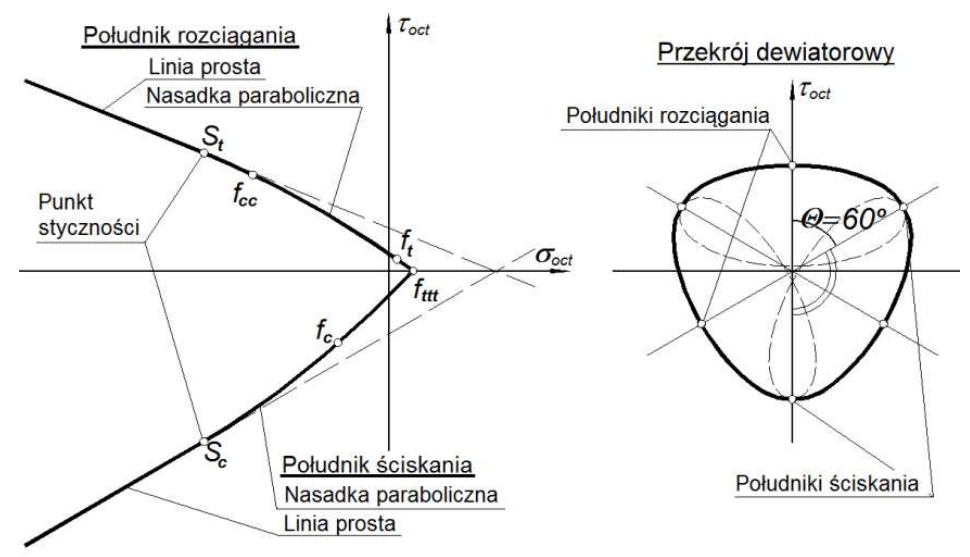

Rys. 1. Ślad powierzchni granicznej w płaszczyźnie południków głównych oraz przekroju dewiatorowym

Fig. 1. Trace of boundary surface in main meridian plane and in deviatoric cross-section

Kształt powierzchni dla materiału konstrukcji został przyjęty na podstawie badań własnych przedstawionych w [9] wykonanych w złożonym stanie naprężenia. Parametry opisujące model betonu oraz gruntu zaczerpnięto $\mathrm{z}$ literatury [5] i [6].

Wygodnym sposobem zobrazowania stanu elementu w trakcie wzrostu obciążeń jest tzw. stopień wytężenia $\left(e_{l e v}\right)(6)$. W ogólnym przypadku w elemencie skończonym występuje złożony stan naprężeń, który można zobrazować, jako punkt $\mathrm{w}$ przestrzeni naprężeń. $Z$ fizykalnego punktu widzenia stan naprężenia w elemencie nie może przekroczyć powierzchni granicznej, natomiast może powodować powiększanie się powierzchni plastyczności do osiągnięcia powierzchni granicznej. Proces ten nazywany jest wzmocnieniem materiału i w przedstawionym zagadnieniu dotyczy elementów gruntowych. Stopień wytężenia podawany $\mathrm{w}$ procentach, jest wartością obrazującą wielkość aktualnych stycznych naprężeń oktaedrycznych $\left(\tau_{o c t}\right)$ do naprężeń znajdujących się na powierzchni granicznej $\left(\tau_{o c t, l i m}\right)$ przy tym samym poziomie normalnych naprężeń oktaedrycznych $\left(\sigma_{o c t}\right)$ oraz kącie Lodego $(\Theta)$. Za zniszczenie materiału elemencie uważa się gdy $\tau_{o c t}=\tau_{o c t, l i m}$, wtedy $e_{l e v}=1,00$. Wartość ta nazywana jest dalej poziomem wytężenia.

$$
e_{l e v}=\frac{\tau_{o c t}\left(\sigma_{o c t}, \Theta\right)}{\tau_{o c t, \text { lim }}\left(\sigma_{o c t}, \Theta\right)}
$$




\section{Model obliczeniowy budowla-podłoże}

Analizie numerycznej z przedstawionym powyżej modelem materiałowym poddano układ ściany typowego budynku mieszkalnego wraz fundamentem oraz podłoża gruntu. Konstrukcja ściany zamodelowana została w różny sposób, od całkowicie niezabezpieczonej, wykonanej z muru ceglanego, do konstrukcji o znacznej sztywności wykonanej z elementami z betonu zbrojonego. Głównym obciążeniem przyłożonym do konstrukcji jest deformacja podłoża $\mathrm{w}$ postaci progu terenowego.

Model obliczeniowy składał się ze ściany o wymiarach 600x300x $25 \mathrm{~cm}$ oraz ławy fundamentowej o przekroju 50x30cm na całej długości ściany. W celu lepszego zobrazowania rozkładu napreżeń w ścianie w zależności od zastosowanych materiałów i elementów konstrukcyjnych przedstawiono trzy układy konstrukcja-podłoże o tych samych wymiarach geometrycznych:

- Model 1 - konstrukcja ściany i fundamentu z muru ceglanego;

- Model 2 - konstrukcja ściany murowana z elementami żelbetowymi wieńca, rdzeni oraz ławy fundamentowej;

- Model 3 - konstrukcja ściany jak w przypadku drugim z otworami - okiennym i drzwiowym.

Geometria układów konstrukcyjnych dla przypadku z otworami okiennym i drzwiowym wraz z podłożem przedstawiona jest na rys. 2. Parametry materiałowe zastosowane do obliczeń pokazano w tablicy 1 . W modelu 2 i 3 zastosowano zbrojenie w narożach przekrojów betonowych prętami $4 \phi 16$ ze stali klasy A-II.

Tablica 1. Parametry zastosowanych materiałów w obliczeniach numerycznych

Table 1. Material parameters used in numerical calculation

\begin{tabular}{|c|c|c|c|c|c|c|c|c|}
\hline & \multicolumn{3}{|c|}{ Mur ceglany } & \multicolumn{3}{|c|}{ Beton } & \multicolumn{2}{|c|}{ Stal zbrojeniowa } \\
\hline & $f_{c}[\mathrm{MPa}]$ & $E_{o}[\mathrm{GPa}]$ & $v[-]$ & $\overline{f_{c}[\mathrm{MPa}]}$ & $E_{o}[\mathrm{GPa}]$ & $v[-]$ & $f_{y}[\mathrm{MPa}]$ & $E_{o}[\mathrm{GPa}]$ \\
\hline Model 1 & 6,5 & 2,1 & 0,22 & - & - & - & - & - \\
\hline Model 2 i 3 & 6,5 & 2,1 & 0,22 & 33,0 & 22,0 & 0,2 & 240,0 & 200,0 \\
\hline
\end{tabular}

Druga część układu budowla-podłoże odwzorowywała grunt o parametrach kąt tarcia wewnętrznego $\varphi=40^{\circ}$ i spójność $c=0$. Odpowiada to bardzo nośnemu gruntowi niespoistemu, który został wprowadzony dla lepszego zobrazowania zachodzących zjawisk pod fundamentem.

Obciążenie konstrukcji przyjęto jako sumaryczne obciążenie stropu $4 \mathrm{kN} / \mathrm{m}^{2}$ o rozpiętości 5m w każdą ze stron i przyłożono w sposób liniowy na górnej krawędzi ściany. Założono, że pod ścianą powstanie deformacja nieciągła w formie progu terenowego o zrzucie $15 \mathrm{~cm}$, którego położenie będzie zmienne. $\mathrm{W}$ ramach tego obciążenia przemieszczano węzły modelu, natomiast parametry materiałowe gruntu są jednakowe dla wszystkich elementów. 
W modelowaniu wykorzystano symetrię układu wzdłuż płaszczyzny pionowej i stąd model obliczeniowy składał się z 4208 elementów prostopadłościennych, które rozmieszczone zostały pomiędzy 5962 węzłami. Elementy prętowe miały 292 szt. i ułożone były w narożach elementów betonowych. Pomiędzy elementy fundamentu i podłoża zostały założone elementy kontaktowe o parametrach podłoża zredukowanych do 1/4. Przemieszczenia podłoża (próg terenowy) podzielono na 45 kroków, co dla jednego kroku obliczeniowego dawało przemieszczenie $0,33 \mathrm{~cm}$. Obliczenia wykonywano przy założeniu, że próg terenowy obejmował różną część fundamentu w granicach od 45 do $495 \mathrm{~cm}$ długości ławy.

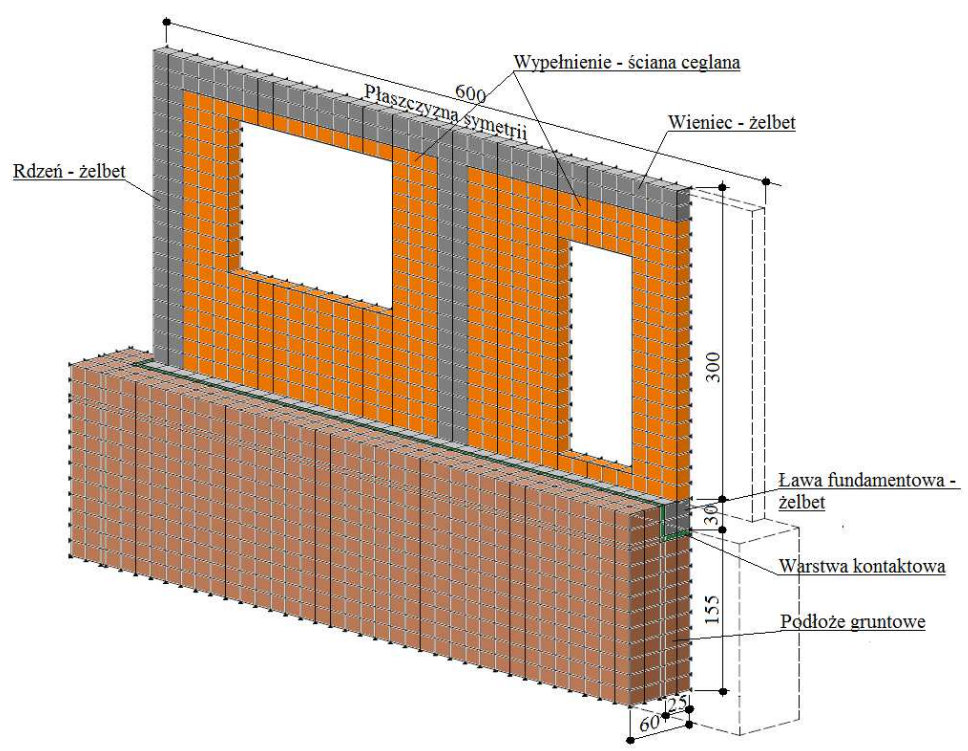

Rys. 2. Model układu budowla-podłoże przyjęty do analizy numerycznej

Fig. 2. Model of soil-structure system for numerical analysis

\section{Wyniki analizy numerycznej}

Analizę numeryczną przeprowadzono zwracając szczególną uwagę na dwie właściwości: zmianę naprężeń, a dokładniej poziomu wytężenia elementów elev konstrukcji ściany oraz zmianę naprężeń pionowych $\sigma_{z}$ w podłożu pod fundamentem na długości ławy.

\subsection{Poziom wytężenia $w$ elementach konstrukcji ściany}

Do analizy wyników obliczeń numerycznych wykorzystano poziom wytężenia (6). Rezultaty obliczeń w postaci barwnych map elementów bryłowych poka- 
zano dla ostatniego kroku obliczeniowego, w przypadku gdy próg terenowy obejmował 7,5\%;32,5\%; $57,5 \%$ i $82,5 \%$ procent długości ściany - odpowiada to progowi znajdującemu się w odległości $45 \mathrm{~cm}, 195 \mathrm{~cm}, 345 \mathrm{~cm}$ i $495 \mathrm{~cm}$ licząc od prawego końca ławy. Kolory ciepłe oznaczają wzrost wytężenia, a czarny wyczerpanie nośności w danym elemencie. Na rysunkach o numerach 3, 4 i 5 przedstawiono zmiany wytężenia elementów w odpowiednio Modelach 1, 2 i 3 przy progu terenowym obejmującym odpowiednią długość ławy fundamentowej.

Rysunek 3. (Model 1) przedstawia ścianę wykonaną wyłącznie $\mathrm{z}$ elementów murowych. Uwagę zwraca podniesiony poziom wytężenia w dolnych elementach ściany do wyczerpania nośności w miejscu połączenia ławy i ściany na krawędzi (rys. 3d). Nie nastąpiło uszkodzenie pionowe ściany, pomimo że deformacja wywołana progiem terenowym była pod środkiem długości ściany.

a)

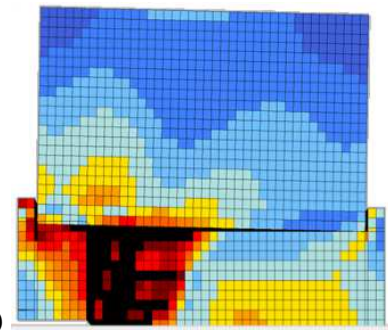

c)

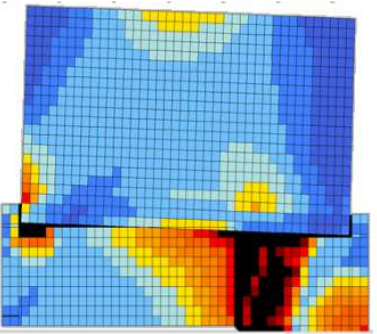

b)

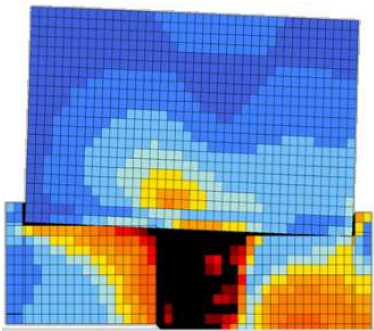

d)

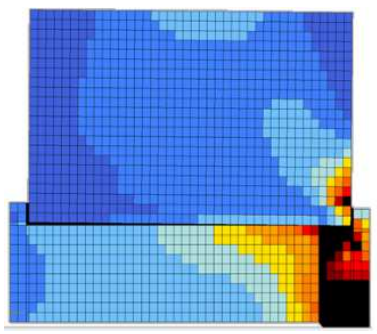

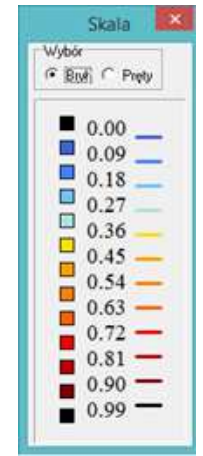

Rys. 3. Wytężenie w elementach Modelu 1 (ściana ceglana) przy progu obejmującym długości ławy: a) $495 \mathrm{~cm}(82,5 \%)$; b) $345 \mathrm{~cm}(57,5 \%)$; c) $195 \mathrm{~cm}(32,5 \%)$; d) $45 \mathrm{~cm}(7,5 \%)$

Fig. 3. Effort level for FE of Model 1 (brick-wall) for a fault including the footing length: a) $495 \mathrm{~cm}$ $(82,5 \%)$; b) $345 \mathrm{~cm}(57,5 \%)$; c) $195 \mathrm{~cm}(32,5 \%)$; d) $45 \mathrm{~cm}(7,5 \%)$

Model 2 (rys. 4.) przedstawia konstrukcję ściany wzmocnioną żelbetowymi rdzeniami, ławą i wieńcem. Beton i zbrojenie wydatnie redukują odkształcenia ściany i tym samym wzrost naprężen oraz wytężeń - nie przekracza on 50\%.

Ściana perforowana otworami (Model 3) poddana jest znacznym wytężeniom. Związane jest to z mniejszą sztywnością konstrukcji i częściowym dopasowaniem się ściany do deformacji terenu, pomimo zastosowania wzmocnień żelbetowych. Na szczególną uwagę zasługuje rys. 5a i 5c, gdzie pojawiły się strefy wyczerpania nośności w narożach otworów. Odkształcenia wywołują zmianę kształtu otworów z prostokątnego na równoległoboczny, a w miejscach 
powstania kąta rozwartego $\mathrm{w}$ narożach występuje rozciąganie, co świadczy o potencjalnej możliwości pojawienia się rysy w kierunku diagonalnej do otworu.

a)

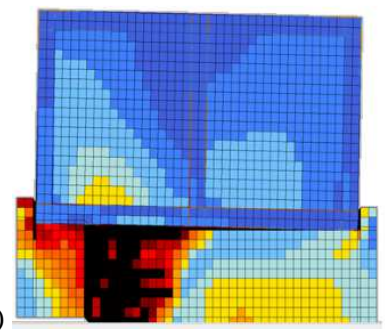

c)

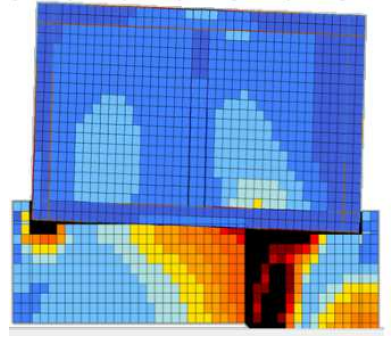

b)

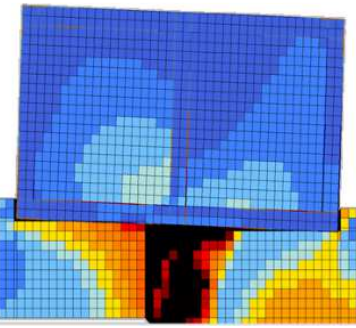

d)

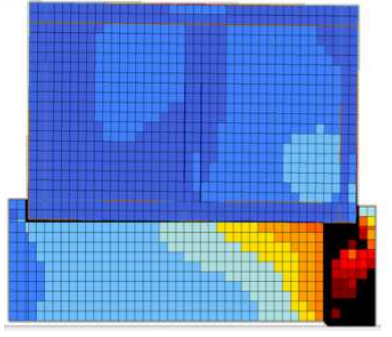

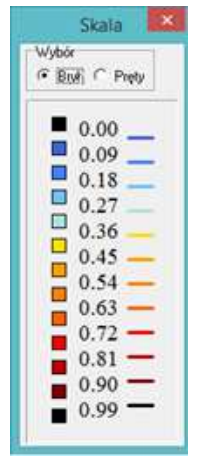

Rys. 4. Wytężenie w elementach Modelu 2 (ściana ceglana z elementami żelbetowymi) - a), b), c), d) jak w rys. 3.

Fig. 4. Effort level for FE of Model 2 (brick-wall with RC elements) - a), b), c), d) - as in fig. 3

a)

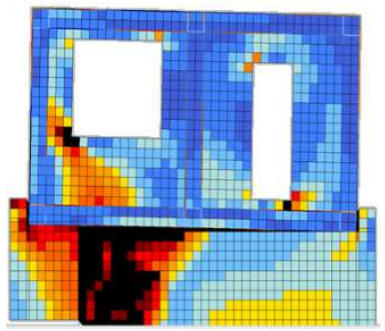

c)

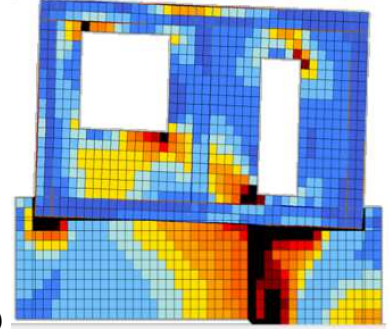

b)

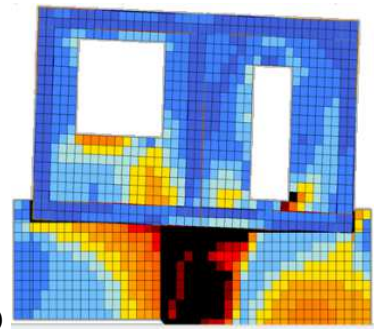

d)

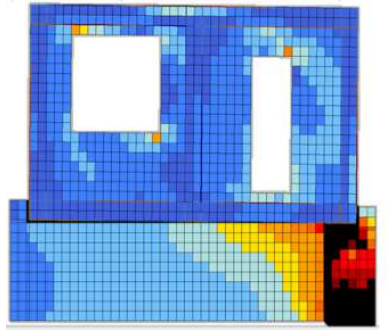

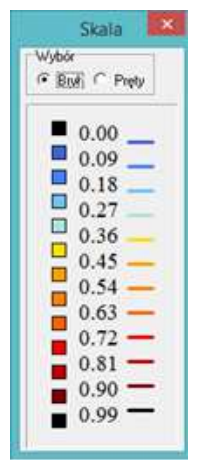

Rys. 5. Wytężenie w elementach Modelu 3 (ściana ceglana z elementami żelbetowymi i otworami okiennym i drzwiowym) - a), b), c), d) - jak w rys. 3 .

Fig. 5. Effort level for FE of Model 3 (brick-wall with RC elements and openings) - a), b), c), d) - as in fig. 3 


\subsection{Zmiany naprężeń pionowych $w$ podłożu pod fundamentem}

Wytężenia elementów gruntowych są znacznie większe niż elementów konstrukcji. Występuje to szczególnie w miejscu wymuszenia przemieszczeń progu terenowego. W strefie, gdzie następuje obniżenie, elementy przylegające bezpośrednio do warstwy progu ulegają uplastycznieniu (wytężenie 99\% - kolor czarny) ze względu na wzajemną interakcję. $Z$ punktu widzenia stanu konstrukcji istotne jest jednak stwierdzenie zmiany naprężeń pionowych $\sigma_{z}$ w podłożu, których wzrost może wywołać uplastycznienie elementów, co będzie skutkowało ewentualnym osiadaniem. Na rysunku 6. przedstawiono jak zmieniają się one przy różnym położeniu progu terenowego w stosunku do długości fundamentu oraz porównano je z naprężeniami pod ławą bez wpływów deformacji podłoża.

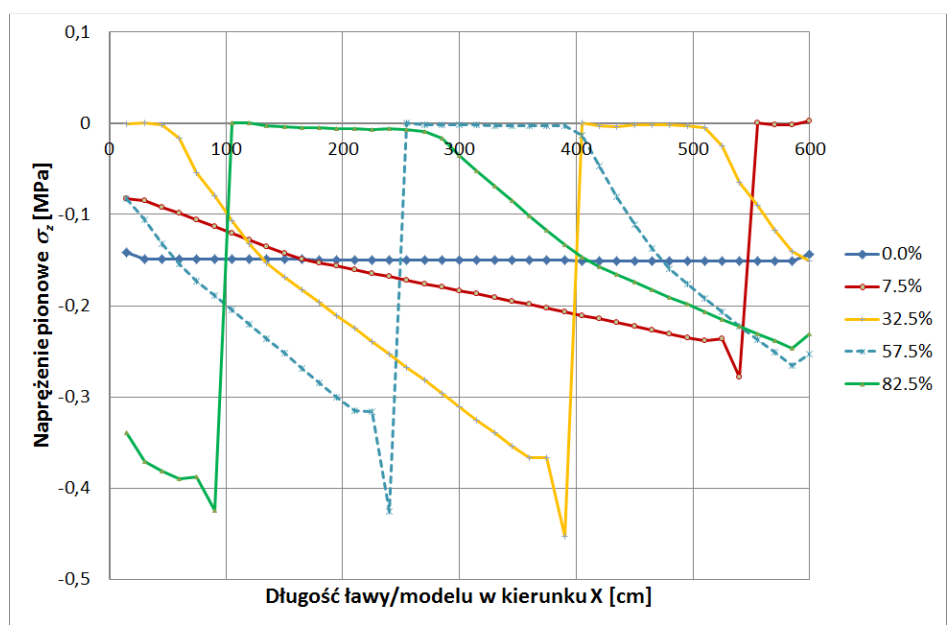

Rys. 6. Zmienność naprężeń $\sigma_{z}$ pod ławą fundamentową w zależności od położenia progu terenowego

Fig. 6. Soil stress $\sigma_{z}$ variability under footing for different fault position

Dla małego zakresu osiadań (7,5\% i 32,5\% długości) można zaobserwować zawiśnięcie fundamentu - redukcja naprężeń $\sigma_{z}$ do zera, a dla większego zakresu (57,5\% i 82,5\% długości) zaraz przy progu następuje redukcja. W miarę jednak oddalania się od progu następuję wzrost naprężeń. W pierwszym przypadku ściana pracuje wspornikowo, a następnie w charakterze belki-tarczy (dwa punkty podparcia). We wszystkich przypadkach następuje znaczny wzrost naprężeń przy krawędzi progu w części, która nie osiadła. W prezentowanym przypadku wzrost jest ponad dwukrotny - 0,15MPa dla przypadku bez deformacji podłoża oraz ponad 0,4MPa dla progu terenowego obejmującego ponad 30\% długości. 


\section{Podsumowanie i wnioski}

Deformacje nieciągłe pochodzenia górniczego występują na powierzchni terenu znacznie rzadziej niż deformacje typu ciągłego. Intensywność oraz szybkość ich ujawniania się wywołuje bardzo gwałtowne obciążenie konstrukcji obiektów. Budynki i obiekty niezabezpieczone na przejęcie takich wpływów w zasadzie nie są w stanie przenieść dodatkowych oddziaływań bez znacznych uszkodzeń, do zniszczenia konstrukcji włącznie.

Przedstawione analizy wskazują na znaczący wzrost odporności budynku gdzie zastosowano wzmocnienia konstrukcji elementami żelbetowymi (Model 2 - rys. 4.). Najistotniejszym wpływem deformacji podłoża jest zmiana sposobu podparcia ławy fundamentowej. Przemieszczenie pionowe części podłoża powoduje powstanie szczeliny, gdy osunięcie się podłoża obejmuje niewielką część fundamentu. Występuje wówczas również pochylenie konstrukcji proporcjonalne do wielkości koncentracji napreżeń w strefie przyprogowej gruntu. Gdy próg terenowy obejmuje większą część fundamentu znaczna koncentracja naprężeń części przyprogowej powoduje pochylenie ściany i wtórne oparcie się końca ściany znajdującego się nad częścią obniżoną podłoża. W takim przypadku elementy ściany pracują początkowo jak wsporniki, a w następnie jak tarcze-belki.

Obniżenie sztywności konstrukcji powoduje powstanie koncentracji naprężeń w miejscach osłabień, narożach otworów. Obszary te są miejscami ujawniania się zarysowań konstrukcji, co jest widoczne na rys. 5. (Model 3). Analiza oddziaływania konstrukcji na grunt pokazuje koncentrację naprężeń przy krawędzi progu. Jeżeli konstrukcja jest dostatecznie sztywna, a położenie progu będzie odległe od krawędzi fundamentu, to należy spodziewać się uplastycznienia podłoża. Pokazuje to wykres zmiany naprężeń pionowych $\sigma_{z}$ w gruncie - rys. 6 .

Przedstawione powyżej obliczenia pokazują możliwość przeprowadzenia obliczeń numerycznych złożonych konstrukcji budowlanych. W niniejszych obliczeniach został zastosowany zaawansowany sprężysto-plastyczny model materiałowy z niekomercyjnego pakietu programów MAFEM3D (autorstwa S. Majewskiego), który pozwala na analizę układu budowla-podłoże gruntowe. Przedstawione wyniki analiz są wstępem do dalszych obliczeń i mają charakter jakościowy. Przewiduje się dalsze analizy w celu określenia zależności ilościowych.

\section{Literatura}

[1] PN-EN 1990 Eurokod. Podstawy projektowania konstrukcji.

[2] Popiołek E.: Ochrona terenów górniczych, Wydawnictwa AGH, Kraków 2009.

[3] Kwiatek J.: Obiekty budowlane na terenach górniczych, Główny Instytut Górnictwa, Katowice 2002.

[4] Kwiatek J. i inni: Ochrona obiektów budowlanych na terenach górniczych, Wydawnictwo Głownego Instytutu Górnictwa, Katowice 1997. 
[5] Majewski S.: Sprężysto-plastyczny model współpracującego układu budynekpodłoże poddanego wpływom górniczych deformacji terenu, Zeszyty Naukowe Politechniki Śląskiej, z. 79, Gliwice 1995.

[6] Majewski S.: Mechanika betonu konstrukcyjnego w ujęciu sprężysto-plastycznym. Wydawnictwo Politechniki Śląskiej, Gliwice 2003.

[7] Zienkiewicz O. C.: Metoda elementów skończonych, Wydawnictwo Arkady, Warszawa 1972.

[8] Willam K. J., Warnke E. P.: Constitutive Models for the Triaxial Behaviour of Concrete. IABSE Seminar on Concrete Structures Subjected to Triaxial Stresses, Bergamo, IABSE Proc. vol. 19, 1974, p. 1-30.

[9] Szojda L.: Analiza numeryczna wpływu nieciągłych deformacji podłoża na budynki ścianowe. Wydawnictwo Politechniki Śląskiej, Gliwice 2009.

\section{NUMERICAL ANALYSIS OF VARIABLE BRICK-WALL STRESS CAUSED BY NON-CONTINUOUS MINING DEFORMATION}

\section{S u m m a r y}

Non-continuous mining deformations appear in mining activity regions. They are not so common as continuous ground deformations. The process of their appearing is violent and a protection of the structure is difficult.

The paper presents a numerical approach to a soil-structures interaction during the activity of ground fault - non-continuous ground deformation. The analysis was carried out by a noncommercial software MAFEM3D created by prof. Majewski. This software uses incrementaliterative procedure of FEM with elastic-plastic material model and isotropic hardening/softening of a material. It allowed to create model of brick-wall structure and the ground which was loaded by the non-continuous ground deformation. The analysis was carried out for one geometric wall shape but with different material parameters and strengthening elements. The loads were implemented as a ground fault which comprised different length of structure footing. The results of calculation were considered for stresses variability of structure and the subsoil. The effort level for finite element showed areas at risk of cracks in structure as well as the ground plasticization process on the edge of the fault.

The numerical analyses gave promising results but they were checked only for one wall structure. The further steps of analyses should be extended to real 3D structures and considered on spatial cooperation of the structural elements like walls, plates etc. In addition the different kind of ground parameters and location below the foundation should be taken in consideration.

Keywords: Non-continuous ground deformation, soil-structure interaction, FEM analysis, elasticplastic material model

Przestano do redakcji: $21.03 .2017 r$.

Przyjęto do druku: : 01.09.2017 r. 